\title{
Investment Related Risk Management Practice by Islamic Banks in Bangladesh
}

\author{
Mohammad Asif Nawaz ${ }^{1, *}$, Umme Farzana ${ }^{2}$ \\ ${ }^{1}$ Department of Banking and Insurance, University of Dhaka, Dhaka, Bangladesh \\ ${ }^{2}$ Agrani Bank Limited, Dhaka, Bangladesh \\ Email address: \\ asifnawaz13@du.ac.bd (M. A. Nawaz) \\ ${ }^{*}$ Corresponding author
}

\section{To cite this article:}

Mohammad Asif Nawaz, Umme Farzana. Investment Related Risk Management Practice by Islamic Banks in Bangladesh. International Journal of Economics, Finance and Management Sciences. Vol. 6, No. 4, 2018, pp. 153-164. doi: 10.11648/j.ijefm.20180604.13

Received: May 29, 2018; Accepted: June 8, 2018; Published: July 10, 2018

\begin{abstract}
Banks are important financial intermediaries for any financial system and the risk management is at the core of banking activities if a bank wants to remain sound and active. Islamic bank is a specialized bank as the nature of operation and the types of risks it face are very different from the interest-based conventional banks and the Islamic banks in Bangladesh are no exception to it. This article attempts to provide information on the various modes of investment followed by the Islamic banks in Bangladesh and current status of the investment related risk management practice. We have tried here to highlight the current growth of Islamic banking in Bangladesh and the most common mechanisms followed by the Islamic banks while investing their funds. The investment here is not the investment in securities but the core banking activity of providing funds to the demander groups. Then we have tried to focus and provide a comprehensive idea and nature of the different types of risks related to the various investment mechanisms after analyzing the features of various investment mechanisms. Afterwards, we have move forward with the discussion and presentation of the core area of this paper, where we have tried to show the common practice of managing investment related risks by the Islamic banks in Bangladesh. Upon analysis our findings reviles that the Islamic banks in Bangladesh currently following the guidelines provided by Bangladesh Bank (central bank of Bangladesh) on risk management which are similar to the practice of interest-based conventional banks. We recommend that depending on the distinct nature of the Islamic Banks, there should be more specific guidelines on risk management solely for these special financial institutions. However, the current practice shows that these banks have already developed their very own guidelines and practice for their betterment and to comply with the Shari'ah rules of doing business.
\end{abstract}

Keywords: Islamic Banking, Investment Modes of Islamic Banks, Risks Related to Investment Modes, Risk Management

\section{Introduction}

Banks are financial institutions engaged in boost in national savings and capital formation as well as constituting infrastructure through financing of various development projects. There are several types of scheduled commercial banks operating in our country. Islamic Banks have discovered a new horizon in the field of banking, and are offering different general banking, investments and foreign exchange services. Islamic banking has opened up a new window of opportunity for those Muslims who are eager to participate in interest-free and Shari'ah complaint banking system. In addition, international financial systems get benefit from diversified financial products and operations, available in Islamic banks, which are characterized by distinct risk-sharing features. From the very beginning since inception the Islamic banks have been facing different kinds of problem due to lack of Islamic Banking Act and Islamic Money Market besides general people have a very little idea about the Islamic modes of operation. These problems have created threats to Islamic banks in managing its investment. Although operating mainly on risk sharing basis, Islamic banks, an integral part of our financial system, are not excluded from risks. There are very distinct and unique risks faced by Islamic banks, which are very different from conventional commercial bank, as Islamic Banks do not operate in the same manner as conventional commercial 
banks. The establishment of the Islamic Finance Standard Board (IFSB) and its guiding principles on Risk Management provided in 2005 reflects the growing importance of prudent risk management system in Islamic banking industry. Consequently, like all other banks, the survival and success of Islamic banks depend on the risk management efficiency. We, in this paper, have focused on every little but significant part of the large iceberg, the investment mechanism and the risks related to it. There are several modes of investment (credit), which are unique in nature. Islamic banks' investment although fulfilling the financing need of the businesses, is not actually credit. Rather it is a Shari'ah compliant mode of helping people in financial need. Some of the investment modes function in profit-loss sharing manner while others function in profitsharing loss bearing manner and some other on rental basis. In this paper we will examine all these modes and associated risks with them.

\subsection{Objectives of the Study}

The main objectives of this study are as follows:

a) Identifying and discussing risks associated with investment (financing business) modes followed by Islamic banks.

b) Highlighting and analyzing investment (credit) risk management practice by Islamic banks in Bangladesh.

\subsection{Methodology}

This paper is descriptive and exploratory in nature, and we have tried to explore the common practices in the industry. All the relevant data and information have been collected from the following primary and secondary sources:

a) Discussion with experienced officers and in-charges in several Islamic Banks.

b) Annual Reports of Bangladesh bank.

c) Guidelines for Islamic banks by Bangladesh bank.

d) Financial Stability Report of Bangladesh bank 2015.

e) Various articles and journals.

\subsection{Limitations of This Study}

The major constraints of the study were the followings:

a) Insufficiency of informationand the conservatism by the banks in providing information.

b) Lack of relevant published documents in the context of Bangladesh.

\section{Literature Review}

Harold Kerzner (2009) has mentioned that a risk management is the practice or act of dealing with risk. It consists of scheduling for risk, recognizing risks, identifying risks, monitoring and controlling risks and developing strategies for risk response to decide how they have modified [3].

Islamic banks, anywhere in the world, are required to stay stick to the Shari'ah principles in all their operations. The pre-determined fixed return (interest) on loans and deposit is not allowed in Islamic Banking and the Islamic banks' resource mobilization and financing are based on profit and risk sharing. Though uncertainty (gharar) is considered unlawful, risk is basic element in Islamic banking industry and obviously there is difference between risk and uncertainty. Islamic bank being alike a normal conventional bank, which also takes deposits and provides financing but in a different manner, is also exposed to same sorts of risks with some additional but of different nature. So the risk management is part and parcel of Islamic Bank too if it desires to survive in the industry with its limited areas of operation.

Mohamed Helmy (2012) in his article highlighted that banking services complied with Shari'ah principles require special treatments for supervision and risk management. He also suggested risk management has gained particular importance in Islamic Banking because of the challenges posed by globalization [6].

H Ahmed (2006) gives importance on the assessment of the risk management system associated with investment mechanisms in Islamic banks and the identification of its strengths and weaknesses for the betterment of the banks [2].

Ilias (2012) investigates in detail the need for risk management in Islamic banks. His research paper shows that in comparison to conventional banks, Islamic banks face bigger difficulties in identifying and managing risks due to bigger complexities emerging from the profit-loss sharing concept and nature of particular risks of Islamic financing [10].

Al-Amine (2008) shows that the risk management infrastructure in Islamic financial institutions needs to identify, measure, control, and monitor all the specific risks in the Islamic financial transactions and instruments [7].

Iqbal \& Greuning (2007) recommend that all staff involved in investment management origination, appraisal, supervision, and other processes need to be trained in Islamic products and fundamental Shariah principles pertaining to defaults, penalties, and invest or rights [4].

Ahmed \& Khan (2001) show a need to introduce a risk management culture in Islamic banks. They propose some ways to introduce such culture. One way to introduce this culture is to initiate some form of internal rating system [12].

Sunitha Kumaran (2012) shows that due to unique nature, the Islamic banks need to develop more rigorous risk identification and management systems. The paper suggests a number of risk mitigation measures available to overcome three major types of risks namely: Investment risk, Liquidity risk and Market risk [11].

So, all these studies have made it clear that risk management is very essential for Islamic banks.

Contribution of the paper

We did not find a single recognized work available on the risk management practices followed by Islamic Banks in Bangladesh. Therefore, here we are trying to draw the 
attention of the various stakeholders and specially the regulators, towards the Islamic Banks' risk management practice and procedures urging to develop and implement a comprehensive risk management guideline for the proper conduct of Islamic banking service in Bangladesh.

\section{Islamic Banking in Bangladesh}

In August 1974, signing the Charter of Islamic Development Bank (IDB) Bangladesh had committed itself to form various financial institutions run on Islamic Shari'ah. Earlier in November 1980, Bangladesh Bank sent a representative to study the working of several Islamic Banks abroad. In November 1982, a delegation of IDB came to Bangladesh and showed their keen interest in establishing a joint venture Islamic Bank in the private sector. At last, in March 1983, the long drawn struggle to establish an Islamic Bank in Bangladesh became a reality and Islami Bank Bangladesh Limited (IBBL) was established. Since then, this sector has grown significantly as reflected in the increased market share. As of December 2017, 9 full-fledged Islamic banks, 20 Islamic banking branches of 9 conventional commercial banks and 25 Islamic banking windows of 7 conventional commercial banks are providing Islamic banking services in Bangladesh. Islamic banking has become a great part of the banking sector in our country and there is huge prospect of having more Islamic banks and financial institutions throughout the country to provide vast majority of Muslim people with the option of earning and saving in interest-free Halal Islamic way.

\section{Investment Mechanisms Followed by Islamic Banks in Bangladesh}

Islamic banks do not directly deal in money. They run business with money. They can be termed as merchants to some extent or traders. The term 'investment' we are using here, in Islamic Banking ideology is the deployment of money to the businesses and to use for development or productive purposes. This is not the investment in securities to earn returns on. The funds collected in Shari'ah compliant deposit mechanisms by Islamic banks in Bangladesh are mainly invested in the following ways:

\subsection{Bai-Modes}

Bai-mode means trading mode of financing whereby the bank trades things required by businesses. The following are the bai-mechanisms:

\subsubsection{Bai-Murabaha}

Bai-Murabaha is a contract between a seller and a buyer where the seller sells certain goods or assets to the buyer at a cost plus agreed profit. The amount then is payable in cash at the spot or on any fixed future date in lump-sum or by installments. The profit added-up may be a fixed amount in lump-sum or in percentage of the cost price of the goods or asset.
Features:

a) Under Bai-Murabaha contract, Islamic bank delivers the specified Goods to the Client on specified date and at specified place of delivery.

b) The bank can take cash or collateral security to guarantee the implementation of the promise or to indemnify the damages.

c) As per contract, the client is permitted to offer an order to purchase by the bank particular goods deciding its specification and committing him to buy the same from the bank on Murabaha, i.e. cost plus agreed upon profit.

\subsubsection{Bai-Istijrar}

Bai-Istijrar is such a contract of buying and selling where a person keeps on taking delivery of required commodities part by part from time to time from a supplier and no offer $\&$ acceptance and bargaining between the mistaken place each time of making and taking deliver.

Features:

a) Under Bai-Istijrar contract, bank enters into agreement separately with the suppliers and the clients to purchase and sell the commodities at agreed price on the basis of Istijrar.

b) Islamic bank delivers the specified Goods to the Client on specified date and at specified place of delivery as per contract.

c) If the seller discloses the price of goods at the time of each transaction then the buyer has to take possession of the goods. The amount is paid after all transactions have been completed.

\subsubsection{Bai-Muajjal}

Bai-Muajjal is a contract between the seller and the buyer under which the seller sells the goods, purchased as per order and specification of the buyer, to the client at an agreed price. The payment of the price is payable at any fixed future date in lump sum or within a fixed period by fixed installments.

Features:

a) As per contract, the client is permitted to offer an order to purchase by the bank particular goods deciding its specification and committing him to buy the same from the bank on Bai-muajjal, i.e. deferred payment sale at fixed price.

b) Under contract, after purchase of goods the bank bears the risk of goods until those are actually delivered to the client.

c) The bank purchases the goods as per specification of the client so stock and availability of goods is a basic condition for signing a Bai-Muajjal agreement.

\subsubsection{BaiSalam}

Bai-Salam is a sale whereby the seller undertakes to supply some specific Commodity to the buyer at a future time in exchange of an advanced price fully paid on the spot.

Features:

a) Collateral security is permitted from the seller client 
to secure the investment from any hazards.

b) Bai-Salam contract is only for agricultural product.

\subsubsection{Istisna'a}

Istisna'a is a contract between a manufacturer and a buyer under which the manufacturer sells specific product after having manufactured, permissible under Islamic Shariah and Law of the Country after having manufactured at an agreed price payable in advance or by installments within a fixed period.

Features:

a) Istisna'a contract gives the buyer opportunity to pay the price in some future dates or by installments.

b) This contract facilitates the manufacturer sometimes to get the price of the goods in advance.

\subsection{Share-Modes}

In share mode profit and loss are shared. There are various methods of sharing and each involves some unique features. They are discussed below.

\subsubsection{Mudaraba}

Mudaraba is a partnership in profit where by one party provides capital and the other party provides skill and labor. The provider of capital is called 'Shahibal-maal', whiles the provider of skill and labor, the manager of the fund, is called 'Mudarib'.

Features:

a) Under this contract, both the parties share the profit as per agreed upon ratio.

b) If there is any loss incurred, the capital provider bears the loss. The Mudarib becomes liable for the loss due to breach of trust.

\subsubsection{Musharaka}

Musharaka may be defined as a contract of partnership between two or more individuals or bodies in which all the partners contribute capital, participate in the management, and share the profit in proportion to their capital or as per pre-agreed ratio and bear the loss in proportion to their capital ratio.

Features:

a) Under this contract, all the partners share the profit in proportion to their capital or as per pre-agreed ratio.

b) If any loss is incurred, partners bear the loss in proportion to their capital/equity ratio.

\subsection{Ijara-Modes}

Ijara mode of investment is alike the leasing mode of conventional commercial bank but in compliance to Islamic Shari'ah. Islamic Banks in Bangladesh follow the following mode of investment under Ijara mode.

Hire Purchase Under Shirkatul Melk

Under this mode Bank may supply goods on rental basis. The ownership of the goods will be with the Bank and the client jointly and the portion of the client will remain to the Bank as mortgage until the closure of the investment account, but the client will be authorized to possess the equipment for certain period. The client, after completion of the installments, will be the owner of the goods.

Features:

i. In Hire Purchase under Shirkatul Melk Agreement, the Shirkatul Melk contract is affected from the day the equity of both parties deposited and the asset is purchased and continues up to the day on which the full title of bank is transferred to the client.

ii. As per contract, the rent is not considered as price or part of price of the asset.

\section{Risks Associated with Investment Mechanisms of Islamic Banks}

Islamic banks face different types of risks associated with investment mechanism. The following table clarifies both types and a definition of each risk:

Table 1. Risks Associated with Investment Mechanisms Followed by Islamic Banks in Bangladesh.

\begin{tabular}{|c|c|c|}
\hline $\begin{array}{l}\text { Types of Common risks associated } \\
\text { with investment mechanism }\end{array}$ & Definition & Investment mechanisms \& its relation with specific risks \\
\hline Non-Repayment risk & $\begin{array}{l}\text { The possibility that borrower } \\
\text { will fail to meet its obligations } \\
\text { of agreed terms and conditions } \\
\text { of a repayment-related contract. }\end{array}$ & $\begin{array}{l}\text { 1. Mudaraba: Islamic banks are exposed to non-repayment risk under } \\
\text { Murabaha because of moral hazard. } \\
\text { 2. Musharaka: Risk is that bank can lose its share in capital invested in } \\
\text { business. } \\
\text { 3. Bai-Murabaha: Risk is that the bank delivers the asset to the Client but the } \\
\text { client can not return the full payment in time. } \\
\text { 4. Ijara: Islamic banks are exposed to non-repayment risk the lessee is unable } \\
\text { to serve the lease rental. } \\
\text { 5. Bai-Salam: Islamic banks are exposed to this risk when specified product is } \\
\text { not delivered on time. } \\
\text { 6. Bai-Istisna: Risk is that the customer is unable to pay the paymen t } \\
\text { obligations for deferred instalments. }\end{array}$ \\
\hline Operational risk & $\begin{array}{l}\text { The chance of financial loss } \\
\text { due to inadequate or failed } \\
\text { internal processes, misconduct } \\
\text { of people and failure of system } \\
\text { or cause of adverse external } \\
\text { events. }\end{array}$ & $\begin{array}{l}\text { 1. Mudaraba: Islamic banks are exposed to risk when banks take excessive } \\
\text { risk with the funds of account holders who have no governance rights over } \\
\text { their management decisions. } \\
2 \text {. Musharaka: Risk is that partner of business lack technical knowledge and } \\
\text { business fails. } \\
\text { 3. Ijara: Risk is that if rented property is damaged, the lessee can refuse to rent } \\
\text { it. }\end{array}$ \\
\hline
\end{tabular}




\begin{tabular}{|c|c|c|}
\hline $\begin{array}{l}\text { Types of Common risks associated } \\
\text { with investment mechanism }\end{array}$ & Definition & Investment mechanisms \& its relation with specific risks \\
\hline Market risk & $\begin{array}{l}\text { The potential impact of adverse } \\
\text { price movements on the } \\
\text { economic value of assets and } \\
\text { equity such as benchmark rates, } \\
\text { foreign exchange rates. }\end{array}$ & $\begin{array}{l}\text { 4. Bai-Salam: Islamic banks are exposed to risk when early delivery of the } \\
\text { commodity is occurred, the bank will have to accept it as long as its } \\
\text { specifications are met. It will then bear additional costs such as warehousing. } \\
\text { 1. Bai-Murabaha: the client may cancel the agreement and bank has to sell the } \\
\text { goods in the open market at a lower price. } \\
\text { 2. Ijara: Risk is that if any default occurs, bank has to re-rent the property on } \\
\text { the open market at a lower price than agreed. } \\
\text { 3. Bai-Salam: Risk is that when the supplier of the Salam contract does not } \\
\text { deliver the commodity under agreement, the bank has to purchase it on the } \\
\text { open market at a higher price. } \\
\text { 4. Bai-Istisna: Risk is that if the customer defaults on the contract, bank it has } \\
\text { to find another buyer and sell the asset at a lower price. }\end{array}$ \\
\hline Liquidity Risk & $\begin{array}{l}\text { The risk that the bank may be } \\
\text { unable to meet short-term } \\
\text { obligations as they become due. } \\
\text { This usually occurs due to } \\
\text { improper planning and } \\
\text { unpredictable surge of cash } \\
\text { receipt and payment. }\end{array}$ & $\begin{array}{l}\text { 1. Murabaha: Islamic banks are exposed to risk when other party cancels the } \\
\text { contract. } \\
\text { 2. Bai-Salam \& Bai-Istisna: Risk arises when client unable to trade under } \\
\text { agreed contract. }\end{array}$ \\
\hline Shari'ah Non-Compliance Risk & $\begin{array}{l}\text { The risk arises when banks do } \\
\text { not follow the rules of Shari'ah. }\end{array}$ & $\begin{array}{l}\text { 1. Mudaraba \& Musharaka: Risk arises when capital invested on prohibited } \\
\text { sectors. } \\
\text { 2. Bai-Murabaha, Bai-Salam \& Bai-Istisna: Risk arises when selling product } \\
\text { is prohibited in Islam. }\end{array}$ \\
\hline Contractual Risk & $\begin{array}{l}\text { Contractual risk is the } \\
\text { possibility of loss incurred due } \\
\text { to the buyer abrogating the } \\
\text { contract, and not because he is } \\
\text { unable to pay. } \\
\text { Legal risk is the risk arising } \\
\text { from failure to comply with } \\
\text { statutory or regulatory } \\
\text { obligations. }\end{array}$ & $\begin{array}{l}\text { 1. Bai-Murabaha, Bai-Salam \& Bai-Istisna: Risk arises when client cancel the } \\
\text { agreement as a result bank has to sell the product to another at lower price. }\end{array}$ \\
\hline
\end{tabular}

\section{Fundamentals of Risk Management and Islamic Banks' Common Practices}

Risk management is the process followed by a financial institution to set a business strategy, to identify the risks to which it is exposed, to quantify those risks, and to take measures to mitigate risks it faces. Risk management is invoked to ensure that banking operations undergo a process of risk identification, risk measurement and risk mitigation in their financial offerings (Rosly, 2014) [9].

Fundamentals of the risk management process comprise of three main features:

i. Establishing an appropriate risk management environment, sound policies, and procedures so risk can be easily identified and preventive measures can be taken earlier.

ii. Maintaining an appropriate risk measurement, mitigating, and monitoring process.

iii. Keeping adequate internal controls in place.

Risk management in Islamic banks incorporates risk measurement, risk management and risk control. Risk management in Islamic banks is also a process to identify, measure, mitigate and monitor risks. An integrated frame work and a day-to-day risk communication throughout the different operating levels are the foundation for a best practice risk management process in Islamic banks. Islamic

banks face many unique risks due to the nature of their operations, particularly Shari'ah compliance requirements (Iqbal \& Greuning, 2009) [4].

\section{Investment Mechanism Related Risk Management Practice of Islamic Banks in Bangladesh}

Risks associated with Islamic banks mentioned before in this paper are managed in similar ways by different Islamic banks. A comprehensive discussion on the management process of all the related risks is presented below:

\subsection{Non-Repayment Risk Management}

Non-Repayment risk is the possibility that the counter party will fail to meet its obligations when it becomes due. According to the annual report, analyses of banking industry data in Bangladesh indicate that $85 \%$ of the total Risk Weighted Asset (RWA) emanated from non-repayment risk while the same was $80 \%$ for Islamic banks. So NonRepayment risk management is an important key factor for Islamic Banks.

In the case of Mudaraba investments, the Islamic bank is exposed to an enhanced non-repayment risk because the Mudaraba contract neither gives the bank rights to monitor the work of Mudarib nor the rights to participate in the 
management. This makes it difficult for the bank to manage the non-repayment risk in this contract.

In Bai-salam or Istisna contracts, the delay or default of supplying the contracted goods on time results in delay or default of payment from the client and exposes the bank to financial losses of income as well as capital.

\subsubsection{Identification and Measurement of Non-Repayment Risk}

Identification is one of the major components of risk management. According to Islami Bank Bangladesh Limited (IBBL) risk management guidelines, Islamic banks in Bangladesh follow identification process in two phases [5]. These are:

a) Pre-Sanction Period

b) Post-Sanction Period

Under pre-sanction period, identification of NonRepayment risk includes proper client selection, due diligence, early alert reporting, and tolerable levels of concentration risk etc.

Under Post-Sanction period, identification of NonRepayment risk includes monitoring the client properly and reviewing Non-Repayment risk policy. The Non-Repayment risk policy is reviewed regularly by the Board of Directors and updated throughout the year to ensure consistency with the Bank's business strategy.

Islamic banks follow the standardized approach for measuring Non-Repayment risk and the Risk Based Capital Adequacy Guideline prescribed by Bangladesh Bank. They also use some measurement techniques such as RWA to total asset ratio, capital adequacy ratio, stress testing etc. Software named CIPPS (Central Investment Proposal Processing System) is used for measuring Non-Repayment risk by some Islamic banks.

Islamic Banks develop an internal investment risk rating system in line with Bangladesh Bank's (BB) regulations and guidelines for its investments inconsistent with the character, volume and convolution of the bank's activities. All investment facilities will be assigned a risk grade. If any deterioration in risk character is observed, the bank immediately changes the risk grade assigned to a borrower and its facilities. Islamic banks also follow Credit Risk Grading manual provided by BB for assessing NonRepayment risk.

\subsubsection{Major Principles of Non-Repayment Risk Management}

After analyzing the risk management guideline of First Security Islami Bank Limited (FSIBL) it is found that there are some major principles of non-repayment risk management. FSIBL as well as other Islamic banks follow these principles. These principles are:

Principle 1: The board of directors of Islamic bank will be responsible for the approval and periodic review of the nonrepayment risk strategy and policies of the bank.

Principle 2: Senior management will have the responsibility to implement the risk strategy and policies approved by the board for managing non-repayment risk.
Principle 3: The bank will have system or procedure in place to identify and manage non-repayment risk inherent in all sorts of contracts.

Principle 4: Islamic banks must operate under sound, welldefined investment-granting criteria. The secriteria will include a thorough understanding of the borrower or counter party, as well as the purpose and structure of the investment, and its source of repayment.

Principle 5: Islamic banks will develop and utilize internal risk rating systems in managing non-repayment risk. The rating system will be in line with the regulatory instructions and consistent with the nature, size, and complexity of activities of the bank.

Principle 6: The Bank will have information systems and analytical techniques that enable management to measure the non-repayment risk inherent in all on balance sheet and offbalance sheet activities.

Principle 7: Islamic banks will establish a system of independent, ongoing investment review and the results of such reviews will be communicated directly to the board and senior management.

\subsubsection{Mitigating Non-Repayment Risk}

For mitigating Non-Repayment risk, risk management committee reviews Non-Repayment risk management process regularly and analyses credit manuals and other written guidelines applied by various departments of a bank and the capacity and performance of all departments involved in the re-payment function. Risk management committee ensures some factors such as:

a) Ensuring that bank has a proper knowledge of the upto-date financial position of the borrower.

b) Ensuring that all investments are in compliance with policies and strategies.

c) Timely identifying and classifying possible problem investments.

Using collateral and pledges as security against NonRepayment risk is a common practice among all Islamic banks for mitigating Non-Repayment risk. In addition to collateral, personal and institutional guarantees are also accepted to minimize this risk and Islamic Banks also maintain provisions for non-repayment risk, as per capital requirement.

Another practice of controlling Non-Repayment risk is the inspection of Shari'ah audit committee. Since February 2016, Shari'ah audit committee is made compulsory for every Islamic Bank in Bangladesh. Shari'ah audit committee ensures that Non-Repayment risk management complies with Shari'ah rules and regulation.

\subsection{Operational Risk Management}

The chance of financial loss due to inadequate or failed internal processes, misconduct of people and failure of system or cause of adverse external events. In this respect operational risk in Islamic banks may arise for the shortage of qualified human resources to conduct the Shari'ah based operations or the banks may not have the available resources 
like computer software in place to conveniently and efficiently run their operations. Therefore, the Islamic banks are more exposed to operational risks now-a-days than other types of banks.

\subsubsection{Operational Risk Management Principles}

After analyzing risk management guidelines of Islamic banks, it is found that Islamic banks follow the following principles to manage operational risk:

Principle1: The board and senior management will ensure that there is an effective, integrated operational risk management framework. This will further ensure that an appropriate organizational structure with clearly indicated roles and responsibilities to manage all aspects of operational risk are in place.

Principle 2: Operational risk policies and procedures that clearly define the way in which all aspects of operational risk are managed will be communicated and documented.

Principle 3: Clear definition and working process of all the business processes will be an essential element for effectively managing operational risk.

Principle 4: The board and senior management will recognize, understand and have defined all categories of operational risk applicable to Islamic banks. Furthermore, they will ensure that operational risk management framework is adequate to cover all of these classes of operational risk.

\subsubsection{Assessing, Monitoring, and Mitigating Operational Risk}

Islamic Banks of Bangladesh adopt standard categorizations of operational risk events according to Event Type and Business Line. Not all Business Lines are relevant for the bank. There are seven major Event Types, and eight major Business Lines, and within each combination of event type and business lines there may be one or more scenario descriptions.

For measuring operational risk, most of the Islamic banks follow Basic Indicator Approach. The other potential ways used by Islamic banks in the identification and assessment of operational risk are, self-risk assessment, risk mapping, and historical data analyses.

a) Self-risk assessment: In this technique bank compares its activities against a list of possible operational risk exposures. Self-risk assessment technique helps in internally identifying the operational risk environment's strengths and weaknesses.

b) Risk mapping: In this process, to find out the potential weaknesses in operational risk management, Islamic banks map their business units, organizational functions or process flows by its risk category. This mapping helps the bank to prioritize management actions.

c) Historical data analyses: This is the empirical analysis of the historical loss experience data of the bank. This process helps in assessing a bank's exposure to operational risk and in developing risk mitigation policy. Islamic banks try to systematically track and record the frequency, severity and other relevant information on several events creating loss for the banks. Banks also combine internal loss data with external loss data, scenario analyses, and risk assessment factors.

Risk indicators (statistics which can provide bank's risk position's insight) like number of failed trade, employee turnover rates, and frequency and/or severity of errors, are also used for measuring operational risk. Islamic banks review risk indicators on a periodic basis to alert the bank to changes that may indicate risk concerns.

Islamic banks monitor their internal process for mitigating operational risk. The regular monitoring helps Islamic banks to quickly detect and correct deficits in the policies, processes, and procedures for operational risk management. To proactively manage this risk, Islamic banks regularly report pertinent information to board and senior management. Senior management establishes a procedure to:

a) Observe the assessment of the exposure of operational risk faced by the bank;

b) Gauge the excellence and suitability of chosen methods of risk mitigation; and

c) Confirm that sufficient control systems are ready to quickly recognize and solve problems before they become major threats.

Besides monitoring, Islamic banks carryout an initial due diligence investigation and oversee the activities of third party providers. They give special concern to those who lacks the experience of regulated environment of banking industry and the bank review this process on a regular basis. For controlling operational risk, senior management creates a risk report. This risk report contains:

a) Internal financial data

b) Data on Operational, compliance, and external market information about conditions and events, which are relevant to decision making.

\subsection{Shari'ah Compliance Risk Management}

Shari'ah compliance risk is the prospective risk to income and equity arising from non-compliance of banks' operation with Shari'ah laws, rules, regulations, prescribed practices, or ethical standards. Banks are exposed to Shari'ah compliance risk due to relations with a great number of stakeholders, regulators, customers, counter parties etc. Since our banking system is under mixed economy, it is a challenge for every Islamic Bank to comply with Shari'ah law.

To comply with Shari'ah, Islamic banks of Bangladesh follow the following AAOIFI (Accounting and Auditing Organization for Islamic Financial Institution) standard as their guidance: 
Table 2. Required issues of the AAOFI Shari' ah Governance Standards for IFIs [1].

\begin{tabular}{|c|c|c|}
\hline AAOIFI Standards & Required issues of the Standards & Total \\
\hline $\begin{array}{l}\text { The Governance Standard for } \\
\text { IFIS No.1: Shari'ah } \\
\text { Supervisory Board: } \\
\text { appointment, composition and } \\
\text { report: }\end{array}$ & $\begin{array}{l}\text { a) The Shari'ah board is an independent body of jurists specialized in fiqh muamalat; } \\
\text { b) Experts in the field of Islamic finance; } \\
\text { c) Direct, review and supervise the activities of IFIs; } \\
\text { d) Affirms the binding authority of the Shari'ah board upon the IFIs; } \\
\text { e) The directors or shareholders of the IFIs cannot be appointed as Shari'ah board members even if they are } \\
\text { qualified to do so. }\end{array}$ & 5 \\
\hline $\begin{array}{l}\text { Governance standard for } \\
\text { IFIsNo.2: Shari'ah Review }\end{array}$ & $\begin{array}{l}\text { a) The Shari'ah board's authority to access all necessary information for the Shari'ah review; } \\
\text { b) The Shari'ah board is only responsible for forming and expressing opinions on the extent of Shari'ah } \\
\text { compliance; } \\
\text { c) The Shari'ah review will be read at the AGM and issued to the management; }\end{array}$ & 3 \\
\hline $\begin{array}{l}\text { Governance standard for IFIs } \\
\text { No.3: Internal Shari'ah review }\end{array}$ & $\begin{array}{l}\text { a) The internal Shari'ah review carried out by an independent department or part of internal audit division; } \\
\text { b) The management and the BOD gave full and continuous support to the internal Shari'ah reviewers; } \\
\text { c) Head of internal Shari'ah reviewers is accountable to BOD; } \\
\text { d) The internal Shari'ah reviewer is proficient and have appropriate academic background and necessary } \\
\text { training relevant to Shari'ah review, particularly proficiency in Shari'ah and fiqh muamalat; } \\
\text { e) The head of the internal Shari'ah review to discuss the findings with the management and the final report } \\
\text { must be addressed to the BODs and copied to the Shari'ah board and management; } \\
\text { f) In the event of disputes between management and } \\
\text { g) Internal Shari'ah reviewers, they are referred to the Shari'ah board for determination; }\end{array}$ & 6 \\
\hline $\begin{array}{l}\text { Governance standard for IFIs } \\
\text { No.4: Audit and governance } \\
\text { committee }\end{array}$ & $\begin{array}{l}\text { a) There is an audit and governance committee (AGC) at the board level; } \\
\text { b) The AGC would consist of a minimum of three members appointed by the BODs from its non-executive } \\
\text { and independent board members who are knowledge about the affairs of the institution, applicable } \\
\text { regulation and laws, including Shari'ah rules and principles; }\end{array}$ & 2 \\
\hline $\begin{array}{l}\text { Governance standard for IFIs } \\
\text { No.5: Independence of the } \\
\text { Shari'ah board }\end{array}$ & $\begin{array}{l}\text { a) The Shari'ah board does not comprise employees of the same IFI who are involved in managerial } \\
\text { decisions and operational responsibilities; } \\
\text { b) Upon assessment, the Shari'ah board conducts continued assessment with the IFIs and does all things } \\
\text { necessary to resolve any issues of independence impairment; }\end{array}$ & 2 \\
\hline
\end{tabular}

Shari'ah compliance level of seven Islamic banks in Bangladesh according to AAOIFI required issues are shown below:

Table 3. Shari'ah compliance level of Islamic banks in Bangladesh (Source: Social Islami Bank Ltd).

\begin{tabular}{|c|c|c|c|c|c|c|c|c|c|c|}
\hline AAOIFI Standard & No. of issues & IBBL & SIBL & SJIBL & EXIM & ICBI & AIBL & FSIBL & Mean & Standard Deviation \\
\hline 1 & 5 & 5 & 5 & 4 & 4 & 5 & 4 & 5 & 4.57 & 0.53 \\
\hline 2 & 3 & 3 & 3 & 3 & 3 & 3 & 3 & 3 & 3.00 & 0.00 \\
\hline 3 & 6 & 6 & 6 & 6 & 6 & 5 & 5 & 6 & 5.71 & 0.49 \\
\hline 4 & 2 & 0 & 0 & 0 & 0 & 0 & 0 & 0 & 0.00 & 0.00 \\
\hline 5 & 2 & 2 & 2 & 2 & 2 & 2 & 2 & 2 & 2.00 & 0.00 \\
\hline Total Compliance (No.) & 18 & 16 & 16 & 15 & 15 & 15 & 14 & 16 & 15.29 & 0.76 \\
\hline Compliance $\%$ & & 89 & 89 & 83 & 83 & 83 & 78 & 89 & 85 & 4 \\
\hline
\end{tabular}

To identify Shari'ah Non-Compliance risk, Shari'ah Board of every Islamic bank keeps keen observations on the day-today transactions of the Bank. The bank declares doubtful transactions as suspended on observation. Every Islamic bank has its own Shari'ah audit committee to assess Shari'ah noncompliance risk. To avoid Shari'ah non-compliance risk by ensuring that all contracts of Islamic bank are in conformity to Shari'ah laws and regulations, Shari'ah board regularly monitor different relevant documentation and banking processes.

\subsection{Market Risk Management}

Market risk is the risk of possible losses of value of onbalance sheet and off-balance sheet positions arising from adverse changes in profit rates, foreign exchange rates, inflation, and commodity prices. Islamic banks are exposed to market risk because of the volatility in the value of tradable, marketable, or leasable assets. In this section we will be discussing the management practice of market risk by Islamic banks in Bangladesh.

\subsubsection{Market Risk Measurement and Mitigation}

Islamic Banks follow Standardized Approach and the Risk Based Capital Adequacy Guidelines issued by Bangladesh Bank for assessing the Market Risk. Besides these, some Islamic banks follow some techniques to measure market risk such as maturity gap analysis and simulation methods are common techniques of measuring market risk. For measuring price risk, most of the banks use duration model.

For managing market risk, Islamic banks have MIS department that ensure proper market information. On the other hand every Islamic bank has its own management board to manage market risk. This board is responsible for making an appropriate framework for pricing, valuation and income recognition. The board is also responsible for wellfunctioning management information systems to control, monitor and report market risk exposure and performance to appropriate levels of senior management. To mitigate market risks, management and board regularly evaluate market risk management policies, procedures, and programs.

Some Islamic banks conduct stress testing to understand 
the actual market condition. Management and board of directors review regularly the results of such stress testing and ensure that if any worst case occurs, a strong contingency plans are in place.

\subsubsection{Profit Rate Risk}

Profit rate risk is the impending effect on bank's profit income and asset values due to the changes in market profit rates on Islamic banks' different products. Profit rate risk arises when an Islamic bank's cash flows from both on-and off-balance sheet items are mismatched.

\section{i. Assessing Profit Rate Risk}

The assessment and management of profit rate risk is not as easy as it is a market force. However, Islamic banks try to safe guard themselves with various measures. Islamic banks assess profit rate risk from the following two perspectives:

a) Earning perspective: In this viewpoint, the impact of profit rate risk on banks' earnings or net profit is assessed. It is very important to assess the impact on earnings as the reduced earnings of a bank can threaten the financial stability by reducing market confidence.

b) Economic value perspective: Changes in profit rates move the economic value of bank's assets and liabilities. The difference between the value of the assets and liabilities is the economic value of the net worth of the bank. This view-point states that the changes in profit rates affect the net worth of the bank and hence increases the chance of bankruptcy.

\section{ii. Managing and Controlling Profit Rate Risk}

To manage profit rate risk Islamic banks, in the first place, try to determine the amount at risk and the possible impact of changes in profit rates on their risk position. To have these determinations ready, Islamic banks prepare appropriate information within acceptable, often very short-time periods. Islamic banks use some measurement techniques like 'value at risk', that precisely and regularly gauge the effect of potential profit rate changes on bank's financial position. Islamic banks also choose appropriate rate scenarios to measure the effect of rate changes. Leveraged adjusted duration gap analysis and simulation techniques are the commonly used by Islamic banks.

To control profit rate risk, most of the Islamic banks make a clear policy. Islamic banks create internal inspection or audit committee to make a clear, understanding policy about profit rate risk. The committee ensures that:

a) Policies and procedures are adhering,

b) There are effective management controls over bank's profit rate risk positions,

c) There are verifications of the sufficiency and correctness of management information reports.

d) Executives involved with profit rate risk management, fully understand bank's profit rate risk policies and have the expertise required to make effective decisions.

\subsubsection{Foreign Exchange Risk Management}

Foreign exchange risk is the potential of loss of earnings or value of foreign exchange position by bank for the unpredictable and adverse movement in foreign exchange rates. In Bangladesh trading in foreign currency for letter of credit or export payments or remittance handling mainly brings foreign currency for banks. The Islamic banks in Bangladesh are also allowed to do the same and they are also exposed to this foreign exchange risk. The banks follow some principles to instantly measure the foreign exchange risk exposure and take actions to mitigate the risk.

\section{i. Foreign Exchange risk Management Policy}

Islamic banks have established a written policy on foreign exchange risk and the major areas of that are as follows:

a) The policy includes statements of foreign exchange risk management principles and objectives.

b) The policy establishes clear and careful limits on the foreign exchange risk exposures of the bank.

c) The policy specifies the levels of personnel having the authority to trade in foreign exchange for the bank.

\section{ii. Foreign Exchange Risk Management Practice}

For measuring foreign exchange risk, Islamic banks make an effective accounting and management information system in their banks. This information helps to measure bank's foreign exchange exposure and the impact of probable exchange rate changes. Islamic banks also maintain monitoring and reporting techniques that measure:

a) The net spot and forward positions in each currency.

b) The aggregate net spot and forward positions in all currencies.

c) Transactional and translational gains and losses relating to trading and structural foreign exchange activities and exposures.

Sometimes Islamic banks make contingency plan to ensure timely access to key information, such as payments made, received or in process, and to develop procedures of obtaining information and support from correspondent institutions. The banks conduct stress testing on timely basis for measuring foreign exchange risk exposure and take actions accordingly.

\subsection{Liquidity Risk Management}

Liquidity risk is the risk that the bank may be unable to meet short-term obligations as they become due. For a number of reasons, Islamic banks are prone to facing serious liquidity risks. Liquidity risk arises because of slow development of financial instruments; Islamic banks are also unable to raise funds quickly from the markets. This problem becomes more serious because there is no inter-Islamic bank money market. On the other hand, the lender of last resort provides emergency liquidity facility to banks whenever needed. The existing lender of last resort facilities in our country are based on interest, therefore Islamic banks cannot benefit from these.

In Murabaha contract bank buys commodity for a client and sells it to him on a markup price to be paid later. Since 
Murabaha receivables are debt payable on maturity they cannot be sold at a price different from the face value in secondary market. This is a source of liquidity risk for the bank, particularly, if average maturities of deposits are shorter than average maturity of Murabaha contracts or if the deposits are sensitive to market returns. It will call the liquidity risk due to non-re-sellable nature of Murabaha primary liquidity risk associated with this instrument.

Salam is an advance payment commodity sales contract where the delivery of the commodity deferred. When a bank signs to purchase a commodity under this kind and pays out the price, its receivable is the commodity due at a specified future date that is specified in the contract. At the time of cash needs the bank is unable to exit the contract by selling it to a third party before maturity because of Shari'ah restriction of not being able to sell what is not in your ownership. This is a source of liquidity risk associated with this instrument.

\subsubsection{Liquidity Risk Management Policies}

Senior management or Asset-Liability Management Committee of Islamic bank approves liquidity risk policy for the bank. The focal points of liquidity risk management policy are as follows:

a) Liquidity risk appetite statement.

b) Statement of the liquidity strategy, goals and objectives.

c) Discussion of the responsibilities of individuals engaged in liquidity risk management.

d) Clear organogram for monitoring, reporting and reviewing liquidity risk.

e) Description of the liquidity risk management tools for identifying, measuring, monitoring, and controlling liquidity risk.

f) Discussion of the contingency plan for handling liquidity crises.

\subsubsection{Liquidity Risk Management Strategy}

Islamic banks establish strategies for the daily management of liquidity risk. The board defined liquidity risk strategy states the following specific policies on certain aspects:

a) About composition of assets and liabilities

This area of strategy will outline the practice of bank for the combination of assets and liabilities to maintain liquidity. Asset-liability management and liquidity risk management will have to be integrated to avoid high costs in readjusting the asset-liability profile of the bank.

b) About diversification and stability of liabilities

To broadly analyze the constancy of liabilities and funding sources Islamic banks identify the following facts:

1. Amount and types of liabilities that would stay with the bank under any situation;

2. Amount and types of liabilities that would run-off slowly if problems arise;

3. The term to maturity of each item included in the liability mix;

c) About managing liquidity in different currencies
Most Islamic banks have a specific strategy on managing liquidity in each foreign currency.

d) About dealing with liquidity disruptions

Every Islamic bank has a strategy to treat the possibility of both short-term and long-term liquidity troubles. The interbank market is an important source of instant liquidity but the strategy should take into account the fact that in crisis situations entry into inter-bank market would be difficult if not costly.

\subsubsection{Managing Liquidity Risk}

To manage liquidity risk, Islamic banks measure receivables from investment instrument such as Murabahah, Ijarah. Banks also measures conditional but predictable cash flows coming from Bai-Salam, Bai-Istisna contract.

Another tool used by most of the Islamic banks is maturity gap approach. The maturity gap approach helps the Islamic banks to identify the net funding requirement in each time horizon. Some banks use ratios such as total investment to total deposits ratio to assess liquidity risk.

Every Islamic bank has its own Asset-Liability Management Committee for monitoring liquidity risk. This committee assesses pricing of assets and liabilities, maturity wise grouping of assets and liabilities for controlling liquidity risk. This committee works for the bank for given purposes:

a) To ensure smooth management of liquidity risk arises from high amount of withdrawals.

b) To ensure recovery against those losses, which occurred due to defaulted customers and this default may give rise to liquidity problem.

Islamic banks prepare a Contingency Funding Plan (CFP) in order to develop comprehensive liquidity risk management framework. The CFP is a set of policies and procedures that serves as guidance for the banks to meet its funding needs in both short-term and long-term needs. Furthermore, it helps a bank to prudently and efficiently manage regular and unusual oscillations in liquidity needs.

Islamic banks mitigate liquidity risk through internal controls. These internal controls make an effective process for identifying and evaluating liquidity risk. Besides these, Islamic banks maintain a margin of excess liquidity as a safety measure.

\subsection{Legal Risk Management}

Legal risk is the risk arising from failure to comply with statutory or regulatory obligations. Islamic banks in Bangladesh are also significantly exposed to legal risks and it arises for various reasons. First, in Bangladesh both conventional and Islamic banks maintain a common law for bank. There are no Islamic banking laws concerning the features of Islamic financial services. Then, there are no legal rules for standard contract system for easier transaction of Islamic instruments. The non-standardization of contracts makes the process of negotiating a transaction very difficult.

\subsubsection{Legal Risk Management Policy}

Legal risk management policy includes important methods 
and procedures to minimize bank's legal risk exposure. Legal risk policy formulated by Islamic banks includes:

a) Definition of legal risk and objectives of its management.

b) Statements of the procedures to identify, assess, monitor, control and manage legal risk.

c) Structure of the information flow of legal risk management at all management levels.

d) Well-defined authorities, responsibilities in managing legal risk.

e) Clearly defined tolerant risk exposure for legal risk.

\subsubsection{Managing Legal Risk}

Every Islamic bank has legal advisor who is responsible to support bank for any legal problem. Besides, risk management committee monitor risk profiles regularly in order to provide management with early warning.

For effective monitoring of legal risk, some Islamic banks have management information system department. MIS department helps to identify and measure bank's legal risk on a timely manner and generate reports to be used by the board and management.

\subsection{Contractual Risk Management}

Contractual risk is the possibility of loss incurred due to the buyer abrogating the contract, and not because he is unable to pay. In Islamic banks, contractual risk arises when another party of Bai-Murabaha, Bai-Salam contract cancels the agreement and bank has to sell the product in the market at a lower rate.

For managing contractual risk, banks carry out a due diligence test on other parties involved in the contract of BaiMurabaha or Bai-Salam. Banks investigate their activities through third parties or from the information they provided in the application form.

Insurance policy is another way followed by Islamic banks to mitigate contractual risk. This insurance policy has to be followed by Islamic Shari'ah. Shari'ah board of the Islamic bank observes the elements of insurance policy.

For controlling contractual risk, risk management committee makes a report about the pros and cons of the other parties. This report contains:

a) Reputation of other parties.

b) Financial stability of other parties.

\section{Findings}

After analyzing investment related risk management practices of Islamic banks in Bangladesh, some positive and negative findings have come out. These finding are listed and discussed below:

a) The Risk Management Committee of Islamic banks are trusted to comply with the risk management guidelines, and monitoring and updating the bank's investment policy. Moreover, the committee regularly investigates the investment portfolio and attempts to restructure the investment portfolio. b) Islamic banks face additional risks due to the nature of their balance sheet and shari'ah compliance.

c) Unavailability of financial instruments to Islamic banks is a major hindrance in their way to manage market risks and liquidity risk as compared to the conventional banks.

d) Owing to religious restrictions, Islamic banks cannot enter the conventional banking market, but the conventional banks are offering the Islamic products simultaneously with their own products. This situation has increased the competition for the Islamic banks and increasing the chance of Shari'ah non-compliance risk.

e) Credit Risk Guideline provided by Bangladesh Bank is appropriate for conventional interest-based banks but not for Islamic banks. So Islamic banks face difficulty to comply with this manual and the management of risk related to investments becomes more difficult.

f) In Bangladesh conventional and Islamic banks adhere to same banking law. There is no specific Islamic Banking Act. Therefore, there is no legal rule of standard contract system for the easier transaction of Islamic instruments and Islamic financial services. The non-standardization of contracts makes the process of negotiating a transaction more difficult.

g) There is no Islamic money market or capital market in Bangladesh. For this instance Islamic banks face challenges to convert a security or hard asset to cash. However, the inter-Islamic bank money market is in initial stage. Therefore, Islamic banks face difficulty to raise funds quickly and to manage their liquidity risk.

h) Al though the Government Islamic Investment Bond (GIIB) has started its journey in Bangladesh, the rate of return is not satisfactory and hence the Islamic banks are not very much interested in this area of operation.

i) Some Islamic banks are not so much technically advanced to mitigate their operational risk.

\section{Recommendations}

Based on our findings, we recommend the following points that can help the Islamic banks manage their investment related risks properly and the regulator can also develop their policy guidelines for the Islamic banks accordingly:

a) There should be a separate risk management guidelines for Islamic banks from Bangladesh Bank.

b) Establishing a separate entity that regulate and supervise the Islamic banks, and remain responsible for regulating the banks in terms of Shari'ah principles and in corresponding with IFSB and AAOIFI.

c) To avoid misconduct of future Islamic financial innovation a clear definition to prohibited terms in Islam like riba and gharar etc. should be introduced.

d) Opening the door for scholars for more financial innovations complied with Islamic Shari'ah.

e) A separate CIB (Credit Information Bureau) reporting system for Islamic Bank investments should be 
introduced.

f) Developing Shari'ah compliant securities market and making ways for Islamic banks.

\section{Conclusion}

The phenomenal growth of Islamic banking industry has forced regulators; industry players and academics to take comprehensive look at overall structure of Islamic bank risks associated with it. There should be a separate risk management framework for Islamic financial institutions specially the Islamic banks, so that these banks can function smoothly. If we are encouraging Islamic financial services in our country and having the benefit as we expected, we should pay attention for the sustainability of the sector. This paper highlights and assesses the management system of risks associated with investment mechanisms of Islamic Banks, a broad area of the Islamic banking. The risk management system of this broad operational area of Islamic banks is very weak and the regulators of the banking sector should come forward to make a standard plan so that they come up with something good for Islamic banks. So it can be concluded that risk management is not a project but a process, therefore, a comprehensive risk management framework and process is the order of the day for sustainability of financial industry more importantly Islamic banking industry.

\section{References}

[1] AAOIFI (1999). Statement on the Purpose and Calculation of the Capital Adequacy Ratio for Islamic Banks.
[2] Ahmed, H.(2006). Risk management assessment systems: an application to Islamic banks.

[3] Kerzner, H., \& Kerzner, H. R. (2017). Project management: a systems approach to planning, scheduling, and controlling. John Wiley \& Sons.

[4] Van Greuning, H., \& Iqbal, Z. (2008). Risk analysis for Islamic banks. World Bank Publications.

[5] Uddin, M. A. (2015). Risk Management Practices in Islamic Bank: A Case Study of Islami Bank Bangladesh Limited.

[6] Helmy, M.(2012). Risk management in Islamic banks.

[7] Nasrallah, F.(2011). Muhammad al-Bashir Muhammad alAmine, Risk Management in Islamic Finance: An Analysis of Derivatives Instruments in Commodity Markets, Leiden and Boston: Brill 2008, 338p. Yearbook of Islamic and Middle Eastern Law Online, 15(1), 369-371.

[8] Rima A. Turk, (2014) "Main Types and Risks of Islamic Banking Products", Regional Workshop on Islamic Banking International Monetary Fund Center for Economics and Finance Kuwait.

[9] Rosly, S. A. (2014). Risk Management of Islamic Financial Institutions. International Centre for Educationin Islamic Finance.

[10] Ilias, S. E. B. (2012). Risk Management in Islamic Banking. DOI: $10.7763 / I P E D$. V55, 32, 159-162.

[11] Kumaran, S.(2012). Risk Management and Mitigation Techniques in Islamic Finance A conceptual framework. International Research Journal of Finance and Economics, 98, 83-97.

[12] Khan, T., \& Ahmed, H.(2001). Risk Management: An Analysis of Issues in Islamic Financial Industry (Occasional Papers) (No. 91). The Islamic Research and Teaching Institute (IRTI). 